\title{
Review for the 12th Slavic Linguistics Society Annual Meeting*
}

\author{
Ivan G. Iliev \\ Plovdiv University, Plovdiv, Bulgaria
}

\begin{abstract}
This is a critical review for the 12th Slavic Linguistics Society Annual Meeting held between the 21st and 24th of September 2017 in Ljubljana (Slovenia). The reviewer prooves with examples that the conference was not organized professionaly and the proceedings from it (in fact, containing only the abstracts of the articles) were not properly reviewed and published. As week points of the book of abstracts, he shows lack of bibliography, unclear abstracts without examples, technical mistakes, etc.
\end{abstract}

Keywords: Slavic Linguistics Society (SLS), 12th SLS Annual Meeting, Ljubljana

Of late, the Slavic Linguistics Society (SLS) has turned into an organization whose main goal is to collect money in the form of annual fees from the latter's members, without allowing many of them to participate in the conferences held each year. The criterion for selecting the members allowed is unclear and is definitely not based on their professional qualities. Proof of that is the carelessly compiled and badly printed collection, reviewed here, of the conference of the SLS held between the 21st and 24th of September 2017 in Ljubljana (Slovenia), containing a huge amount of weak abstracts with insipid and imprecise titles. From them, in most cases, it does not even become clear what the articles deal with. Let alone the presence of illustrative examples which as a rule are lacking, and even less any scholarly contribution in them. In many cases, the abstracts are accompanied by ridiculously few titles in the bibliography containing, with some exceptions, mostly works in English. The compilation in the form it has throws serious doubt over both the professional qualities of the conference's organizing committee and over those of the reviewers.

One hundred and thirteen abstracts are presented in the collection. The working languages in it are English, Russian, and Slovenian, but there are abstracts which are presented in one of the Slavic languages only, without an English variant (for instance, the one by Mislav Benić-Пересказывание дискурса на примере говора Осиека и окрестностей, pp. 43-44, just in Russian, etc.). Such an ill-prepared collection I have not seen even in Asia. One could say printing it was a pure waste of paper. The titles in many cases are imprecise and there are instances of wrong spelling - as the one on p. 62: "The reflexes of jat in East-Bosnian ijekavian-shtokavian speech type noted in the surveys Questions about the speech of the populace (1897) and Bosnian-Herzegovinian dialectal complex (1975-1986)", where Questions about the speech of the populace is neither put in quotes nor is it in italics. There are also some irritating type errors in the text of the abstracts (see below).

I will not tackle all the materials but just a few of them. The collection starts with presenting one of the

\footnotetext{
* Book of Abstracts 2017 (Editors: L. Repanšek and M. Šekli), Založba, Ljubljana, 268 pages, ISBN 978-961-05-0027-8. Ivan G. Iliev, Ph. D., associate professor, Department of Humanities, Kardzhali Campus, Plovdiv University, Plovdiv, Bulgaria.
} 
weakest articles in it by Georg Holzer from Wien University, Austria, entitled Proto-Slavic syntax in the Freising Fragments and other old Slavic documents (p. 26). From this chaotic and senseless half-page text not including a single example and no concrete conclusions, the reader can understand absolutely nothing about the research topic, which sounds something, like the category of case in German and the other Germanic languages. It remains unclear from how many and which regions the Freising Fragments and the "other" Slavic documents originate, how many in number those "other" Slavic documents are, which they are (not one of them gets mentioned, neither are their editions given in the bibliography), from what epoch they date and on what principle they were selected in comparison with the Freising Fragments. Looking at the scant bibliography which lacks fundamental works of scholars, like Leskien, Meillet, and van Wijk, one is left with the impression that the report was only dedicated to the absolute cases in certain Slavic languages-one of the categories regarding which conclusions about its pre-Slavic state can be made in the slightest degree. And even if that research dealt with that only, the titles shown are ridiculously few in number. Many of the sentences in the abstract, if not all, lack meaning. For example, Proto-Slavic syntax can only be understood as the syntax that starts from the etymological rather than the "standard" interpretation of conjunctive pronouns and adverbs. Who could explain what pre-Slavic syntax is, given the fact that almost nothing is known about it! Particularly about conjunctions, which are different in the three groups of contemporary Slavic languages. I would recommend to Holzer one of the books on the matter, which I will discuss below.

And what should I say about abstracts like the one by Vladimir Plungian (On "secondary word-forms" (in Russian and cross-linguistically) with as many as three (!) titles in the bibliography (pp. 28-29), about the abstract by Vrinda Chidambaran-Morphologically incorporated universal quantifiers in superlatives: Evidence from Slovene (pp. 56-57) even with a single title, or about Pedagogical dialogues as sources for the history of address and linguistic politeness in Slavic languages by Michael Betsch (pp. 45-46)! Actually, the last work is interesting as an idea to show the history of forms of polite address in Slavic languages, but superficially written, badly fashioned and imprecisely titled. There is no introduction, which would explain what types of systems for expressing politeness exist in those languages (second person, third person, probably other, too). Reading the abstract, it becomes apparent that to Betsch the "Slavic languages" are exhausted with Czech and Slovenian, and there is no mention what sources the examples were taken from (just the years of issue are indicated). Additionally, it is unclear why in it we often encounter forms written as identi?able, re?ect, re?ected, considering the fact that they do not demand spelling out with a special font.

The drive toward generalizing processes and phenomena concerning all Slavic languages, but with examples from only several of them is also present in A. Będkowska-Kopczyk's article-What and how can we feel in Slavic? A cognitive analysis of constructions with verbs expressing "to feel" (pp. 47-48). The authoress in question, in contrast to the previous author, at least uses one language from the three big Slavic groups (concretely: Polish, Russian, Slovenian, and Serbo-Croatian). In the similarly poor bibliography, at least one Russian or Serbo-Croatian grammar is absent, but, in compensation, one can see a research paper dealing with the Central-American Maya language!

Another telling example of the voiding of sense the presence of an abstract in the collection is Paola Bocale's article The role of the distal deictic "man" in expressing irrealis modality in spoken Russian (pp. 51-52). The reader will not understand a thing from what's given by Bocale, because not one illustrative sentence 
is shown in context from which it could become clear in what function the mentioned deictic "there" is used, which in some of the cases could also designate the sentence topic.

As a Bulgarian, I would not miss Tsvetana Dimitrova's abstract-Variation in clitic placement in the history of Bulgarian (pp. 70-71) - another telling example of a grandiose title that does not correspond to the article's contents. Because what is being discussed is not the history of Bulgarian but the state of several monuments. The clitics as a whole fail to be researched, just a few of them are. What is more, there is no explanation why just "pronominal clitics" of the type $м$ "me", ce "myself, yourself etc." were selected on one side, and several "discourse clitics" of which no examples are provided in context, as was done with the pronominal ones, and the latter in many cases could not be clitics but relative postfixes of the -mo type in the relative pronoun койmo "whoever". There is no list of abbreviations attached to the abstract, although such are profusely used in the text. The grammatical clarifications of the pronominal clitics in the examples are not given in parenthesis or below them, but inappropriately inserted into the text ( $i$ vb vodon i ACC bi pogubil "and he would kill him in the water"; ašte mi DAT sę REFL kl'učitb ... "if I have the opportunity ...", etc.). I will certainly repeat and re-repeat, but for a piece of research so pretentious in its title it is ridiculous to have just three cited sources. Let us suppose the authoress has not heard of my research of the historical development of Bulgarian relative pronouns and the elements linked to them (Iliev, 2012). There exists, however, a vast other literature on the subject by Bulgarian, Czech, and other researchers which I will not enumerate here. The same criticism I direct to Wojciech Guz's article—On że-relatives in spoken Polish: A corpus study (pp. 85-86)—again with only two titles indicated in the bibliography.

The paper by Maxim Makartsev, Max Wahlström, and Teodora Vuković-The use of infinitive in peripheral Serbian dialects and language maintenance (pp. 117-118), with a joint effort and an "exhaustive" citation of two titles again from the existing several score or hundreds written on the topic, tries to solve an important Balkanistic issue of the competition of the infinitive and the constructions displacing it in two Serbian dialects, one of which is both "Serbian" and "transitional between Serbian and Bulgarian/Macedonian"!?

Petar Vuković's article-Bunjevci from Bačka: Language situation (pp. 198-199) not just manifests the incompetence of its author in respect of the matter being researched (an early work by A. Dulichenko pronounces this Slavic dialect a micro-language, but Vuković is obviously ignorant of his arguments) and the wobbly mastery of the German of the sources he has cited, but also a frank distortion of scientific truth and what was provided by previous authors tackling the issue.

In the amateurish, as a whole, collection there are after all several valuable abstracts of articles: The Slavic word for "spider" by Marko Snoj (pp. 34-35), A corpus outlook on regional varieties of Russian in Daghestan by M. Daniel and A. Panova, or The origin of Proto-Slavic *čbjb “whose” by Marek Majer (pp. 115-116). Interesting as a conception is Jan Ivar Bjørnflaten's (pp. 49-50)—Reanalysis in the Russian past tense: Northwest Russian past tense forms in -vši, cf. "ušodši”" versus "ušël" (here we could search for a link to the old uses of absolute case forms). But even those works cannot change the unpleasant impression that the goals of the organizers of the successive SLS Conference in Ljubljana was not heightening the prestige of Slavistics, but the several days of enjoyment of a group of privileged members of the organization on the money of others. This assertion of mine is graphically proved by the motto of the held conference: Let's drink in honour of all languages ...!/Пьем за все языки ...!, with which Matej Šekli’s introductory speech ends (pp. 20/22). 


\section{References}

Iliev, Iv. G. (2012). Theory of relativity. The Bulgarian relative pronouns: Origin and development (in Bulgarian). Vessela. Plovdiv. 